\title{
喉頭癌に対する経口的切除術
}

富 藤 雅 之. 荒木幸 仁・宇 野 光 祐
木 村栄子. 塩 谷彰浩

\section{Transoral Surgery for Laryngeal Cancer}

\author{
Masayuki Tomifuji, Koji Araki, Kosuke Uno, \\ Eiko Kimura and Akihiro Shiotani
}

\begin{abstract}
Treatment of laryngeal cancer mainly consists of radiation therapy, chemoradiotherapy and surgery. For organ preservation surgery, transoral surgery or open partial laryngectomy are the treatments of choice. Of these, transoral surgery is the least invasive, allowing for a direct approach to the lesions. In our institution, we practice two modalities for transoral surgery. Transoral laser microsurgery (TLM) is indicated for glottic cancer, which has a narrow working space. In contrast, transoral videolaryngoscopic surgery (TOVS) is indicated for supraglottic cancer, since the working space is relatively wide and the lesion can be visualized from various directions using a laryngeal endoscope. In glottic initial cases (Tis, T1-2 and 1 case of T3), the 5-year overall survival (OS), disease-specific survival (DSS), larynx preservation rate (LPR), local control rate (LCR) and laryngoesophageal dysfunction-free survival (LEDFS) were $90.3 \%, 95.7 \%, 95.1 \%, 78.5 \%$ and $75.2 \%$, respectively. Good oncological results can be expected in Tis, T1-T2 glottic cancer; however, T1b cases are not a good indication for TLM because of the high incidence of glottic web formation. In radiorecurrent salvage TLM for rT1-rT2 lesion, the 5-year OS, DSS, LPR, LCR and LEDFS were 86.2\%, 91.3\%, 83.9\%, 71.8\% and 67.3\%, respectively. Acceptable oncological results were obtained for $\mathrm{rT} 1-\mathrm{rT} 2$ lesions. A relatively large surgical margin is recommended in radiorecurrent cancer. In supraglottic cancer with T1-T3 lesions, the 5-year OS, DSS, LPR, LCR and LEDFS were $73.0 \%, 88.2 \%, 89.4 \%, 88.1 \%$ and $67.3 \%$, respectively. A good organ preservation rate was achieved, and the swallowing function was preserved except for in one case. Considering the laryngeal cancer treatment guidelines, T1-T2 and rT1-rT2 lesions can be indicated for transoral surgery, and in experienced institutions, select T 3 lesion can also be indicated for transoral surgery.
\end{abstract}

Keywords : laryngeal cancer, transoral surgery, minimally invasive surgery, laryngeal function preservation surgery

\section{は じめに}

喉頭癌は悪性腫瘍としては比較的治りやすい部類に入 り，2016 年に国立がん研究センターから発表された 10 年 生存率初集計に扔いても喉頭癌全症例の 10 年相対生存率 は $71.9 \%$ と比較的良好な生存率が示されている. 本統計 は 1999 年から 2002 年とやや古い時期のものであるが手 術率については $37.3 \%$ と比較的低い割合であり, 従来よ り放射線治療 radiation（以下RT）あるいは化学放射線治 療 chemoradiation（以下CRT）が行われる例が多いものと 考えられる ${ }^{1)}$. 現在においても喉頭癌の治療は放射線治療 を主体とした治療と手術を主体とした治療法に大別される が，適応も重なることが多いため対象患者には各治療法の 利点，欠点执よび当該施設に扔ける治療成績を含めて説明 することが望ましいと考える。

喉頭癌に対する手術を主体とした治療法には経口的切
除, 頸部外切開から行う喉頭部分切除術 (垂直部分切除術, 水平部分切除術), 喉頭严全摘手術 (supracricoid partial laryngectomy with cricohyoidoepiglottopexy or cricohyoidopexy), 喉頭全摘術などが代表的な術式として行われて いる. 外科的治療の中では経口的切除術は病巣に直接的に アプローチして, 病巣とその周囲組織のみを切除するとい う点で最も低侵襲であることは言うまでもないことである が, 腫瘍学的治療成績や機能的な面からその適応と限界に ついて自験例拉よび国内外のデータから考察していきたい.

\section{喉頭癌治療における経口的手術の位置づけ}

当院に扔ける声門癌，声門上癌に対する経口的手術の位 置づけを表 1 に示す. 声門癌は声門上癌に比して限局した 病変が多く，また鉗子類の操作スペースも限られているた め顕微鏡下のレーザー手術 (Transoral Laser Microsurgery: TLM $)^{2)}$ を行い, 比較的広範囲の視野と操作スペースが得

防衛医科大学校耳鼻咽喉科学講座

Department of Otolaryngology, Head and Neck Surgery, National Defense Medical College 
られる声門上部においては拡張型喉頭鏡と内視鏡を用いた 手術 Transoral Videolaryngoscopic Surgery $(\mathrm{TOVS})^{3,4)}$ 行っている.いずれも手術適応としてはTisから T1, T2 が主体であり，T3 症例には症例を限って適応となること がある。声門癌の T 3 例（傍声帯間隙浸潤例，画像診断上 甲状軟骨に接する症例）に扔いても喉頭直達鏡下の触診で 甲状軟骨との間に可動性がみられれば経口的に切除可能と 判断しうるが, 術前より声帯固定をきたしているような症 例に拀いては輪状披裂関節を確実に切除する必要があるた め外切開部切などの適応と考えている。声門上癌の T 3 例 に扔いては喉頭蓋前間隙, 輪状後部, 傍声帯間隙浸潤例が
症例によっては適応となりうるが，舌骨や甲状軟骨浸潤例 は適応外であり, 機能的な面も考えると喉頭蓋前間隙にお いて舌骨に達しない程度の浸潤をきたした症例がよい適応 と思われる。

\section{声門癌}

方法, 対象例

当院に打ける声門癌に対するレーザー切除は 2001 年か ら 2009 年 2 月まではファイバー型の KTP レーザーを使用 しており，2009年 3 月以後はマイクロマニピュレーター で操作する $\mathrm{CO}_{2}$ レーザーを使用している. Steinerらの報

表 1 当科に拈ける喉頭癌治療方針

\begin{tabular}{|c|c|c|c|}
\hline \multicolumn{2}{|l|}{ 声門癌 } & \multicolumn{2}{|c|}{ 声門上癌 } \\
\hline Tis & TLM & Tis & TOVS \\
\hline $\mathrm{T} 1 \mathrm{a}$ & TLM or RT & $\mathrm{T} 1$ & TOVS or RT \\
\hline $\mathrm{T} 1 \mathrm{~b}$ & RT or TLM & & \\
\hline T2 表層 & TLM or RT & T2 & TOVS or RT/CRT \\
\hline T2 深部 & OPL or TLM or RT/CRT & & \\
\hline T3 & OPL or CRT or (TLM) or TL & T3 & CRT or (TOVS) or TL \\
\hline T4 & TL or (CRT) & T4 & TL or (CRT) \\
\hline
\end{tabular}

CRT: chemoradiation, OPL: open partial laryngectomy, RT: radiation, TL: total laryngectomy, TLM: transoral laser microsurgery, TOVS: transoral videolaryngoscopic surgery,

\begin{tabular}{|c|c|c|c|}
\hline 男性 & 156 例 & & \\
\hline 女性 & 11 例 & & \\
\hline KTPレーザー & 54 例 & & \\
\hline $\mathrm{CO}_{2}$ レーザー & 113 例 & & \\
\hline 初回治療 & 140 例 & RT/CRT後サルベージ & 27 例 \\
\hline Tis & 13 & & \\
\hline T1a & 83 & rT1a & 9 \\
\hline $\mathrm{T} 1 \mathrm{~b}$ & 19 & rT $1 b$ & 5 \\
\hline $\mathrm{T} 2$ & 24 & $\mathrm{rT} 2$ & 13 \\
\hline T3 & 1 & & \\
\hline \multicolumn{4}{|l|}{ すべてN0 症例 } \\
\hline \multicolumn{4}{|c|}{ ELS 分類（分類可能な 132 例において） } \\
\hline Type I & 10 & $(8 \%)$ & \\
\hline Type II & 33 & $(25 \%)$ & \\
\hline Type III & 48 & $(36 \%)$ & \\
\hline Type IV & 11 & $(8 \%)$ & \\
\hline Type V & 19 & $(15 \%)$ & \\
\hline Type VI & 11 & $(8 \%)$ & \\
\hline
\end{tabular}


告したTLM ${ }^{5)}$ では多分割切除が基本であるが，当院では 腫瘍の一塊切除を基本として扮り, 手術中に迅速病理診断 を行い, 必要に応じて追加切除を行う方針としている。本 稿では 2001 年から 2016 年 12 月までにレーザー手術を施 行した 167 例を解析の対象とした。対象例の内訳を表 2 に 示すが, 大多数を初回治療の $\mathrm{T} 1 \mathrm{a}$ 症例が占めており, 次 にT2 症例が多い結果であった，放射線治療後のサルベー ジ手術はrT1, rT2 に施行されていた。切除の範囲は European Laryngological Society (ELS) 分類 ${ }^{6,7)}$ で評価し えた 132 例について分類したが， T1 a 症例が多いことから 多くはType II (声帯勒帯までの切除), Type III（声帯筋 層での切除）といった比較的限局した切除例が占めてい た。最も深部まで切除した症例としては傍声帯間隙浸潤を 伴いT3 と判断された症例に行ったType VI切除であるが, 本症例は術前の喉頭ストロボスコピーで若干声帯が摇れる
ような所見があり，甲状軟骨との明らかな癒着はないもの と考えられたためTLMにて切除しえたものであるが, 術 後 5 年以上無再発生存が得られている.

\section{治療成績}

治療成績の評価として粗生存率 (overall survival: OS), 疾患特異的生存率 (disease specific survival: DSS), 喉頭 温存率 (larynx preservation rate: LPR), 局所制御率 (local control rate: LCR), 2009 年 にLarynx Preservation Consensus Panel が設定したlaryngo-esophageal dysfunction-free survival: LEDFS ${ }^{8}$ (死亡, 局所再発, 喉頭部分切 除・全摘, 治療後 2 年時または以降の気管切開孔残存・経 管栄養・胃瘦をすべて eventとする指標) で評価を行った。

声門癌初回治療例 140 例（観察期間中央值 61 力月）の成 績は 5 年 OS 90.3\%, DSS 95.7\%, LPR 95.1\%, LCR 78.5\%,

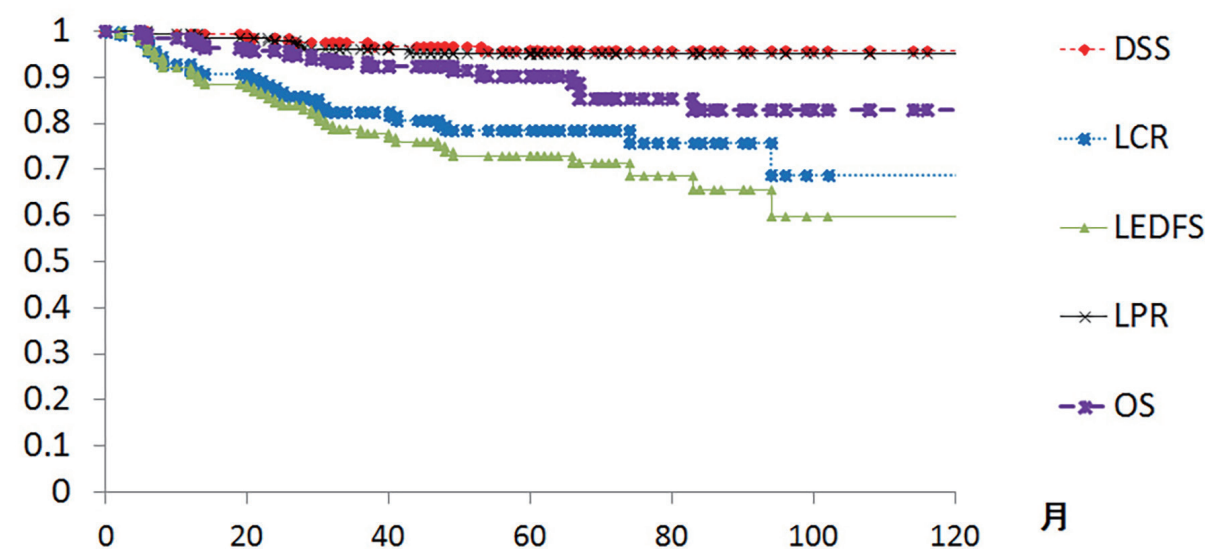

図 1 声門癌レーザー治療（初回例）の成績 Tis-T2, 一部 T $3, \mathrm{n}=140$

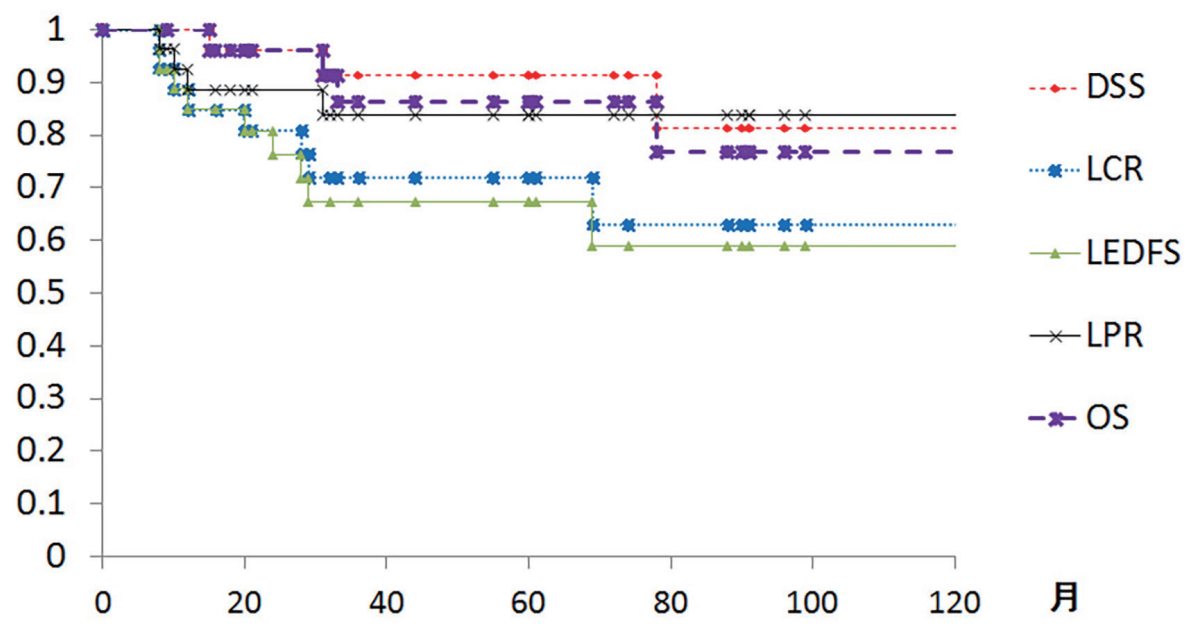

図 2 声門癌サルベージレーザー治療の成績 rT1-rT2, n=27 
LEDFS 75.2\%であった（図 1).90\% 台の良好な生存率, 臓器温存率が得られていたが, 局所制御率については $80 \%$ 弱であり単回ではなく複数回のレーザー切除で喉頭 温存が得られている症例が一定数存在するという結果で あったＬEDFSについてはほぼLCRと同等であり，単回 での局所制御が得られていない症例があるため低下してい たが，燕下障害による打ち切り例は見られなかった。燕下 機能についてはType VI切除例で嚥下機能回復に日数を要 した症例がみられたものの概ね 2 週間以内に経口摂取を回 復しており，嚥下障害が長期化した症例は声門癌に関して はみられなかった。

局所制御率についてさらにT分類別に検討してみたとこ 万 5 年LCRは Tis $84.6 \%$, T $1 \mathrm{a} 86.4 \%, \mathrm{~T} 1 \mathrm{~b} 51.3 \%, \mathrm{~T} 2$ 69.3\%であった，T1bの成績不良の原因としては医療機器 や手術を行った時期も関係しており, 古い時代のKTP レーザーでは 5 年 LCRが $25 \%(\mathrm{n}=8), \mathrm{CO}_{2}$ レーザーでは $71.5 \%(\mathrm{n}=11)$ であった。症例数が少ないため有意差まで は見られなかったが $(\mathrm{p}=0.072)$ ，レーザー機器の更新 （KTPレーザーの場合照射中にフィルタが掛かるため映像 としては見づらくなるという欠点があった）および癌の表 在性進展部位の診断力の向上（上皮下の微小血管網が透見 できない部位も含めて切除する)により改善がみられたと 思われる。T1b初回治療例については19例にレーザー治 療を行っていたが，問題点としては声带webの形成率が高 い $(16 / 19)$ こが挙げられる. 声带長の $1 / 2$ 以上の web が11例にみられ，1例に瘉着切除とステント留置による 追加治療が行われた。声帯長の $1 / 2$ 以下のwebは 5 例に みられ, web形成しないものは 3 例であった，左右の声帯 を二期的にレーザー切除した症例もあったが，結果的には 声帯長 $1 / 2$ 以下ではあるがwebを形成した。前交連が残 せるような連続しない両側声帯病変や僅かに前交連を超え る程度までの切除であればwebを形成しにくいという結果 であった。

次に声門癌 RT/CRT後のサルベージTLMの成績につい て検討した。サルベージ症例 27 例（観察期間中央值 60 か 月）の成績は 5 年 OS 86.2\%, DSS 91.3\%, LPR 83.9\%, LCR 71.8\%, LEDFS 67.3\%であった（図 2)，初回治療例 よりは若干成績が劣るものの，再発例においても $80 \%$ 台 の喉頭機能温存が達成できており rT $1, \mathrm{rT} 2$ 症例までであ ればサルベージTLMの適応はあると考えられる。サル ベージTLMに扔ける注意点としては腫瘍の進展範囲がわ かりにくいこと，粘膜表面というよりは粘膜下に再発がみ られることも多いため十分に深く広めの切除範囲を取った ほうがよいということが挙げられる．実際大部分の症例が ELS分類としてはType $\mathrm{V} \sim \mathrm{VI}$ といった甲状軟骨膜に達す るまでの切除が行われていた。

表 3 声門上癌TOVS 症例 2004 2017年 27 例

\begin{tabular}{lccc}
\hline \hline & T1 & T2 & T3 \\
\hline N0 & 9 & 6 & 2 \\
N1 & 1 & 1 & \\
N2 & & 7 & \\
N3 & & 1 & \\
\hline
\end{tabular}

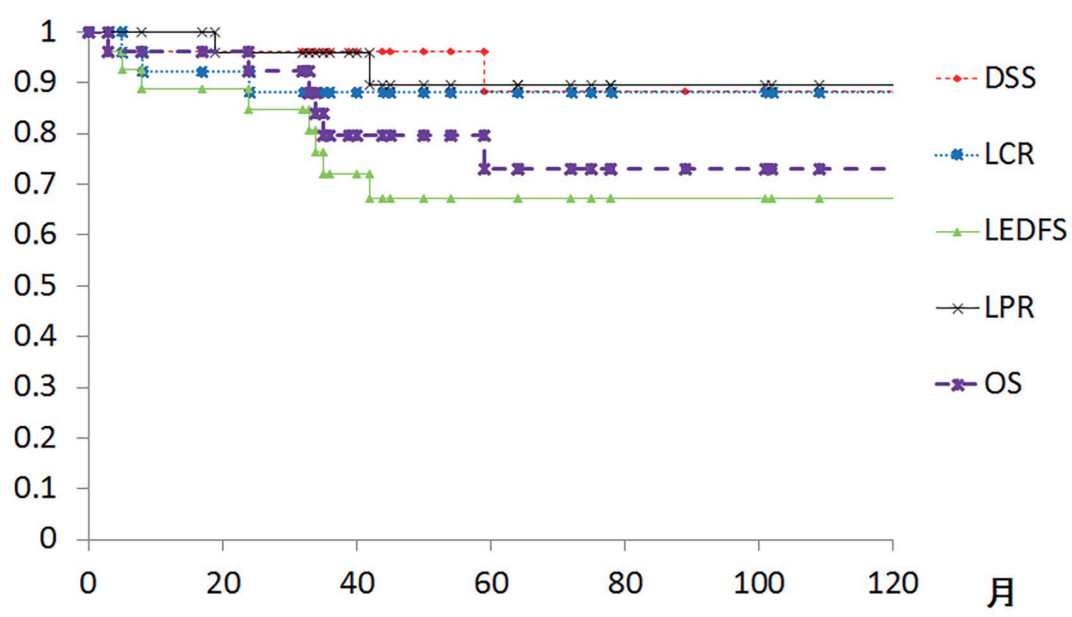

図 3 声門上癌 TOVSの成績 T1-T3, N0-N3, n=27 


\section{声 門 上癌}

\section{方法, 対象例}

2004 年 10 月から 2017 年 9 月までにTOVSを施行した 声門上癌経口的切除 27 例を解析の対象とした。 TNM分類 については表 3 に示す通りで全例 M0 症例であり, 病期と してはStage I : II : III:IVは 9:6:4:8であった. TOVS の方法についてはすでに報告 ${ }^{9)} し て お り$ 詳細は割愛する が, 近年では malleable deviceも用いて幅広い領域に対応 が可能となっている，声門上癌は声門癌とは異なりリンパ 節転移がみられる症例も多く、リンパ節転移陽性の症例に 対しては基本的には同時, 症例によっては二期的に頸部郭 清術を施行している. 深部断端陽性, 頸部リンパ節転移(後 発も含め) N2 以上, 節外浸潤が術後放射線治療の適応と しており，7例に術後RT/CRT（4 例/3 例）が施行された.

\section{治療成績}

各種治療成績は観察期間中央值 50 か月で 5 年 OS $73.0 \%$, DSS 88.2\%, LPR 89.4\%, LCR 88.1\%, LEDFS 67.3\%で あった (図 3 )。術後 $2 \sim 3$ 年の間で他癌死 (肺癌, 食道癌) がみられたためOS抢よびLEDFSの低下を認めたが，原疾 患についてはコントロール良好であり，喉頭温存率も良好 であった。術後與下機能についてはFOSSによる評価 ${ }^{10)}(0$ ～5の 6 段階評価）を治療後半年に行っており，FOSS 0 2 が 22 例，嚥下に注意を要するFOSS 3 が 4 例 (14\%), 急速な頸部再発のため評価不能が 1 例であった，FOSS 3 が多くみられたのは喉頭蓋全切除例であったが，喉頭蓋全 切除した 8 例中 3 例に嚥下障害がみられたものの食形態の 工夫で経口摂取を維持できており，胃㾞増設を要した症例 はなかった，気管切開については 4 例において周術期管理 のために施行したが，長期的に閉鎖不能の例はなかった。

\section{ガイドラインからみた喉頭癌に対する経口的切除の適応}

本邦に扔ける治療指針である頭頸部癌診療ガイドライン 2018 年版 ${ }^{11)}$ によると Tis 病変は内視鏡切除・経口的切除 の適応とされており, T1, T2, T3病変に対しては喉頭温 存手術 (内視鏡切除術, 経口的切除術, 喉頭部分切除時術, 喉頭覀全摘術を含む)の適応とされている。 T1～T3 にお ける喉頭温存手術の使い分けについてはクリニカルクエス チョンに沶いてT1, rT1に対しては主に経口的切除術, T2,rT2 以上に対しては頸部外切開手術が想定されてい る。また音声に関しても経口的レーザー切除と放射線治療 は同等であるという報告が多いとされている。

海外に扔ける喉頭癌治療のガイドラインとしては American society of clinical oncology（ASCO）による喉頭 癌治療に関するガイドラインが 2018 年に更新されてい る ${ }^{12)}$ 。経口的切除術に関する記載もあり，以下に要約を 列挙する。

・T1, T2 病変に対しては手術または放射線治療で喉頭温
存を目指すべきである

・経口的切除術と放射線治療は同等の成績であるが，でき るだけシンプルな治療を行うべきであり，広範囲の dysplasia病変, 腫瘍の浸潤範囲がわかりにくく術後放射 線治療を必要とするような症例はよい適応ではない

・治療選択に扔いて考慮すべき点として腫瘍体積, 声帯可 動性, 前交連浸潤, リンパ節転移, 年齢, 職業, 治療前の 音声機能, 嚥下機能, 治療施設へのアクセスなどが挙げら れている

・T3 症例に関してはASCOガイドラインにおける推奨は ないものの文献紹介 ${ }^{13)}$ はされている. 122 例の声門癌 pT3 病変に対するTLMの成績として $5 \mathrm{y}$ OS 58.6\%, recurrence free survival (RFS) $57.8 \%$, DSS $84.1 \%$, larynx preservation rate $83 \%$ が取り上げられており，T3 病変に対する CCRT $^{14)}$ (5y OS 67\%, DSS 79\%, Laryngectomy free survival 62\%) やSupracricoid resection ${ }^{15)}$ (5 y local control rate $91.4 \%$, laryngeal preservation 89.8\%) と同等と述べられている.

以下はASCO ガイドラインとは別の内容になるが，さら に進行した T 4 a喉頭癌に対するTLMの成績が Göttingen university から報告されている ${ }^{16)}$ 。術後 (化学) 放射線治 療を $39 \%$ の症例に施行しているが5y organ preservation rate $80 \%$, LCR $67.2 \%$, 5y OS $55.8 \%$, Recurrence Free Survival $61.9 \%$, DSS 71.8\%の成績が得られており, 喉頭 全摘と同等の生存率で喉頭機能温存に寄与したとされてい る.

喉頭局所進行癌 T 3 ～T 4 症例に対する TLM と頸部外切 開部分切除open partial laryngectomy (OPL) のメ夕解析 による比較試験 ${ }^{17)} も$ 行われており，5 年OSがTLM $69 \%$ に対してOPL $73 \%(\mathrm{p}=0.518) ， 5$ 年DFSがTLM $76 \%$ に 対してOPL $83 \%(\mathrm{p}=0.118)$ とOS, DFS ともに有意差は ないもののOPLのほうが少し成績は良い傾向にある.

これらの報告を考慮すると T 3 以上の症例に対する TLM は経験豊富な施設なら適応ともなりうるが，一般的 には外切開部分切除による手術か他の治療法 (化学放射線 治療ないしは喉頭全摘術）を選択するのがよいと考える。

\section{ま と め}

喉頭癌に対する経口的切除の適応としては $\mathrm{T} 1, \mathrm{~T} 2$, (rT1〜 T2) 病変が主体である. Tisから T $1 \mathrm{a}, \mathrm{T} 2$ がよい 適応であるがT $1 b$ 症例についてはwebの形成やそれに伴 う音声障害が生じうるため適応は慎重に判断する必要があ る。経験豊富な施設においては一部の T 3 症例も対象とな り得るが，一般的には外科的治療の中では外切開部分切除 術のほうが若干良い成績が得られている。

利益相反の該当する事項は無い 


\section{参 考 文 献}

1) https://www.ncc.go.jp/jp/information/pr_release/ 2016/0120/press_release_20160120.pdf

2) Steiner W: Results of curative laser microsurgery of laryngeal carcinomas. Am J Otolaryngol 14 : 116-121, 1993

3) Shiotani A, Tomifuji M, Araki K et al : Videolaryngoscopic transoral en bloc resection of supraglottic and hypopharyngeal cancers using laparoscopic surgical instruments. Ann Otol Rhinol Laryngol 119 : 225-232, 2010.

4) Tomifuji M, Araki K, Shiotani A et al : Transoral videolaryngoscopic surgery for oropharyngeal, hypopharyngeal, and supraglottic cancer. Eur Arch Otorhinolaryngol 271 : 589-597, 2014.

5) Steiner W, Ambrosch P : Endoscopic laser surgery of the upper aerodigestive tract. Thieme, New York, 37 82, 2000.

6) Remacle M, Eckel HE, Antonelli A et al : Endoscopic cordectomy. A proposal for a classification by the Working Committee, European Laryngological Society. Eur Arch Otorhinolaryngol 257 : 227-231, 2000.

7) Remacle M, Van Haverbeke C, Eckel H et al : Proposal for revision of the European Laryngological Society classification of endoscopic cordectomies. Eur Arch Otorhinolaryngol 264 : 499-504, 2007.

8) Lefebvre JL, Ang KK : Larynx Preservation Consensus Panel. Larynx preservation clinical trial design : key issues and recommendations-a consensus panel summary. Head Neck 31 : 429-441, 2009.

9）富藤雅之, 塩谷彰浩：咽喉頭癌に対する経口的切除 Transoral videolaryngoscopic surgery (TOVS). 喉頭 30:73-78, 2018.

10) Salassa JR : A functional outcome swallowing scale for staging oropharyngeal dysphagia. Dig Dis $17: 230$ 234, 1999.

11）頭頸部癌診療ガイドライン 2018 年版, 日本頭頸部学 会編 55-121，金原出版，東京，2017.

12) Forastiere AA, Ismaila N, Lewin JS et al : Use of larynx-preservation strategies in the treatment of laryngeal cancer : American society of clinical oncology clinical practice guideline update. J Clin Oncol 36 : 1143-1169, 2018.

13) Canis M, Martin A, Steiner $W$ et al : Transoral laser microsurgery in treatment of pT2 and pT 3 glottic laryngeal squamous cell carcinoma-results of 391 patients. Head Neck 36 : 859-866, 2014.

14) Fuller CD, Mohamed AS, Garden AS et al : Long-term outcomes after multidisciplinary management of T3 laryngeal squamous cell carcinomas : Improved functional outcomes and survival with modern therapeutic approaches. Head Neck 38 : 1739-1751, 2016.

15) Dufour X, Hans S, De Mones E et al : Local control after supracricoid partial laryngectomy for "advanced" endolaryngeal squamous cell carcinoma classified as T 3. Arch Otolaryngol Head Neck Surg 130 : 1092 1099, 2004

16) Canis $M$, Ihler F, Steiner $W$ et al : Organ preservation in T 4 a laryngeal cancer : is transoral laser microsurgery an option? Eur Arch Otorhinolaryngol 270 : 27192727, 2013.

17) Mannelli G, Lazio MS, Luparello $P$ et al : Conservative treatment for advanced T3-T4 laryngeal cancer : meta-analysis of key oncological outcomes. Eur Arch Otorhinolaryngol 275 : 27-38, 2018.

別刷請求先 $\bar{\uparrow} 359-8513$ 埼玉県所沢市並木 3-2 防衛医科大学校耳鼻咽喉科学講座 冨藤雅之 